\title{
Analysis of Component of Aggression in the Stories of Elementary School Aggressive Children
}

\author{
Fateme Chamandar $^{1} \&$ D. Susan Jabbari ${ }^{1}$ \\ ${ }^{1}$ Department of Exceptional Children, Shiraz University, Iran \\ Correspondence: D. Susan Jabbari, Department of Exceptional Children, Shiraz University, Iran. Tel: \\ 98-917-316-2123. E-mail: SfJabbari@yahoo.com
}

Received: December 17, 2016

Accepted: January 3, $2016 \quad$ Online Published: January 16, 2017

doi:10.5539/jel.v6n2p187

URL: http://dx.doi.org/10.5539/jel.v6n2p187

\begin{abstract}
The purpose of this study is the content analysis of children's stories based on the components of aggression. Participants are 66 elementary school students (16 girls and 50 boys) selected from fourth and fifth grades, using the Relational and Overt Aggression Questionnaire; completed by the teachers. Draw a Story Test (Silver, 2005) is administered to select aggressive children who narrates stories based on their drawn pictures in response to DAS pictures. DAS Test consists of a series of figures which children respond by drawing a picture and telling a story related to the picture. This provides us with the information about their self image and emotional content. After deciding the components of aggression based on theories of Crick et al. (1997), and Crick and Dodge (1996), the stories are analyzed using the quantitative content analysis technique. The results reveals that the narrated stories of aggressive children have engagement ratio of 1.62 , which means more than $50 \%$ of children showed aggressive components. The highest frequency of aggression in their stories is related to murdering, killing and hurting others.
\end{abstract}

Keywords: story, aggressive, components of aggression, and elementary school

\section{Introduction}

The stories we tell or hear indicate who we are. They are the body of our experiences and go us beyond our life (past, future or even now). Children cannot reach the ability of reading and writing without living in the world of stories. Children, between the ages of 1 to 8, move through an extraordinary path; from the first words they express to the most complex ones and sometimes they are eager to tell a story (Susan Engel, 1995).

Usually, we suppose that the stories written by great writers are complex, meaningful and deserve to analyze but deny the simple, beautiful and comparatively clear stories with strange construction told by children. While we can use these stories as a means to recognize their tensions and feelings and understand what they cannot express. The stories children tell, the way they play, or the image they reflex in their writings, all are effective in knowing the narrator children, more (Susan Engel, 1995).

Whenever a child describes an experience about himself or someone else, he is building his past and also he is expressing his feeling about who he is and how he feels about others. In fact, when a child makes a story about possible events happening for himself or others, he is improving his world (Susan Engel, 1995).

The imaginary or real stories told by children, show their experiences, ideas and their importance. They improve their personality through stories. The meaningful stories by children can be interesting and different (Susan Engel, 1995).

Children look at stories as a cognitive solution in their complex world, they also use stories for making emotional feelings among themselves and the people around them. For young children who can't express their feeling, drawing or telling a story can be a means to cope with the word limitation and a means to analyze and bring some information about how they think or feel (Silver, 1989). Children' stories can be as important as their parents, teachers and researchers for us since they give us an insight about how children with different ages experience the world and also how they think and feel. An increasing number of researchers discover that stories and narration are critical for children and their growth (Susan Engel, 1995). The investigation of children' self-image and emotional content through drawing and narrating a story is highly important to understand their problems-which can't be expressed in any ways, especially aggression. 
Aggression is a basic and common problem at schools. According to teachers reports, 15 percent of children are the victim of aggression and toughness. According to students reports about 50 percent of children are engaged (Mack Niel, 2002; said by Silver, 2005). Avoiding from aggression at schools is one of the priorities of education in today's world.

Aggressive behavior is a strong disagreement with others and often results in social rejection and avoidance. Aggression includes short-time rewards like controlling the surroundings, become important and despising others (Walker, Hops, \& Greenwood, 1993; said by Walker, Colvin, \& Ramsey, 1995) which has a strong impression on peers which finally cause to his rejection from peers. Some aggressive children are unaware of their behavior causes them to be rejected (Walker \& colleagues, 1995). Aggressive children have serious problems in their social relationships. For example, they have misunderstanding think about the evaluation of other's motivations and this social behavior purpose and, they often have a wrong interpretation about these behaviors and follow hostile purposes in other's behavior and react inappropriately toward them (Walker \& colleagues, 1995).

There are two kinds of aggression; and overt and relational aggression. Overt aggression refers to physical activities like beating, pushing, kicking, throwing and threating which are aimed to hurt others (Crick \& Grot peter, 1995). Overt aggression consist of physical, reactive and proactive aggression.

Reactive and proactive aggressions are seperate subdivisions of overt aggression; proactive aggression is an intentional behavior with the aim of reaching some tools to frighten or rule, over others, and he is motivated by external rewards. For example boxing another child to reach his favorite thing. On the other hand, reactive aggression refers to defensive actions against the received threat and perceiving other's behavior as a threat or deliberation which is mostly shown by an angry face (Dodge, 1993), such as boxing a peer when he pushes him just for fun.

The present research aims to analyze the content of aggressive children' stories and responds the bellow question: To what extent does the story content affect the aggression component?

\section{Methodology}

In the present study, since the aggression components in the stories told by children were studied, the researcher uses the documentary method and the quantitative content analysis (conceptual approach) the researcher decided just appoints the quantitative content frequency of the text which is called the purposeful (oriented) content analysis by Mazidi ( 2006) (said by Hossein Chari \& Asadpour, 2007).

Moreover, analyzing the quantitative content technique is; a technical method used in researches for exploring the overt content of communication quantitatively and objective (Yarali, 2005). The fourder of the quantitative content technique is Berlson and its source is communication science. Content analysis is used to recognize the analytic units containing aggression components and allocate them to the introduced categories and also account the engagement ratio of aggression components of each story. Paragraphs are the analytic units in this research.

\subsection{Research Group}

The population of this study contains all students of Shiraz elementary schools in 2009-2010. The documents of content analysis including all stories told by 66 aggressive students is the sample of this study.

The method of sampling for this study is two-part. In the first part, the sample is collected randomly and the second part is purposefulin which we asked teachers of 5 schools from different areas of Shiraz to select maximally 10 students, whom they know well and without considering their educational level (successful or unsuccessful), the teacher were asked to fill the behavior problems questionnaire of Quay and Paterson (Shahim, Yusefi, \& Qanbari, 2007), the Conners' teacher classified scale form (Shahim, Yusefi, \& Shahaian, 2007) and the scale of overt aggression (Shahim, 2006). Finally, 66 children (16 girls and 50 boys) were selected and analysed through Silver's Drawing a Story Test (2005).

The aim of this study is to analyse the amount of aggression in the stories narrated by children in reaction to DAS test' pictures and to investigate how much the expressed words and sentences contain aggression. To analyize the amount of aggression components in the stories the method of analysing quantitative content was used to prepare a collection of aggression components in the stories of aggressive children. Three main aggression factors from Crick, Casas and Mosher Approach (1997) were used; 1) Physical aggression (Beating, killing, biting and physical abuse), 2) Proactive aggression (Start fighting or threatening to fight, Start beating, Start cursing and shouting and Start throwing objects, the damage and start injuries to others and start damage to property), and 3) Reactive aggression (Reply by fighting or threatening to fight, Reply via beating, Reply by swearing and shouting, Reply by 
throwing objects, Response to injury and death and injury to others and response through damage to property), and then the aggressive texts by children were decided and analyzed.

In this research, the engagement ratio is obtained from dividing the total of aggression units by non-aggression units. The resulting coefficient is $0 / 5$ indicating that at least 25 percent of the analytic units are aggressive and if it was 1 then 50 percent of the analytic units were aggressive, at least. Therefore, engagement ratio less than $0 / 5$ shows that stories contain more aggressive components and the higher ratios indicate the best condition of stories.

\subsection{Data Collection Tool}

\subsubsection{Draw a Story Test (DAS)}

Silver's Draw a Story Test (DAS) (2005) is used in this research. DAS test is based on the interpretation that the analyst can prepare an image from the evaluation of self-image through analyzing the drawing of the experienced. By analyzing the self-image we mean the main personality in drawing which is intentionally or unintentionally introduce the drawer. Usually, children project their main personality through a story (Silver, 2005). In evaluating with DAS, first motion pictures are presented to the children and then asked them to select two of them and draw a picture. Then, we asked the child to tell a story related to the drawing which would be the indicator of emotional content. This artistic evaluation pays more attention to the content of the drawing than the artistic features (like color, quality of the lines and etc.).

Silver recommended the DAS test in order to evaluate and distinguish the overt, withdrawal and depressed aggressive children (Silver, 1989, 2005). The validity and reliability of DAS on a group of aggressive children have been considered and reported in Iran (Shahim \& Razmjuee, 1388; Chamandar, Shahim, Mazidi, \& Seif, 1391).

(A)
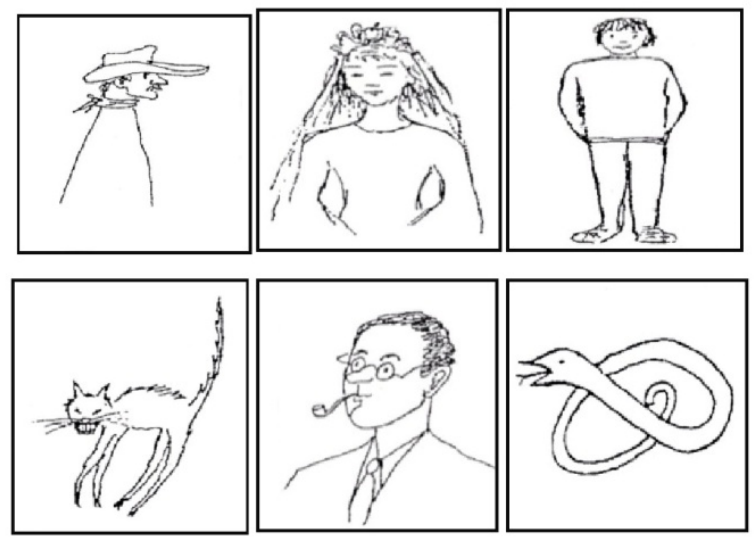

(ب)
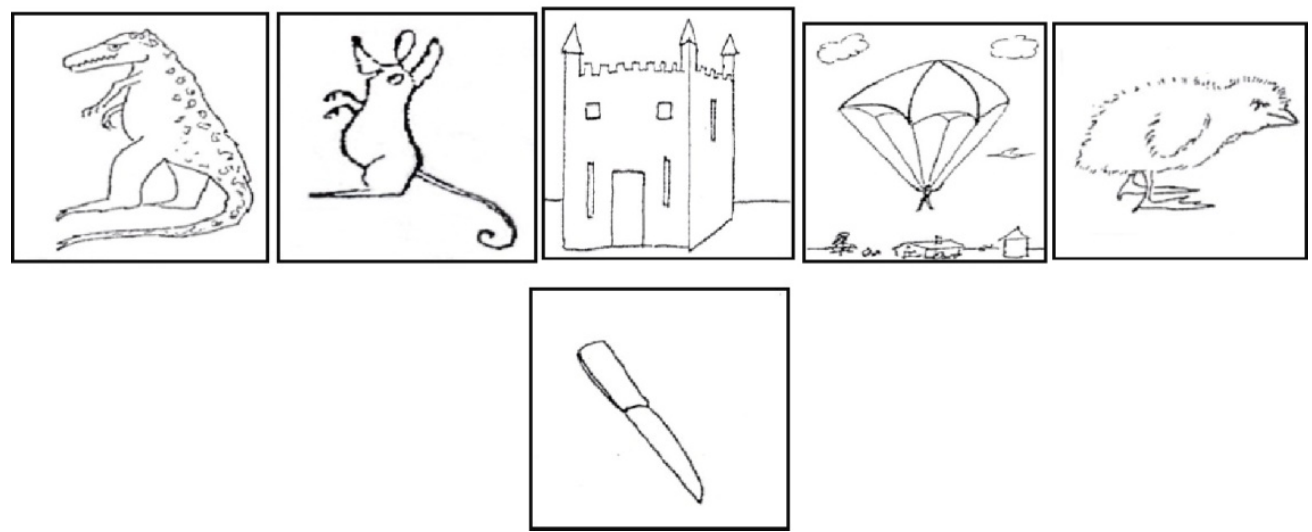

Figure 1. Motion pictures in drawing a story 
Below some samples of aggressive children's stories with their drawings are analyzed.

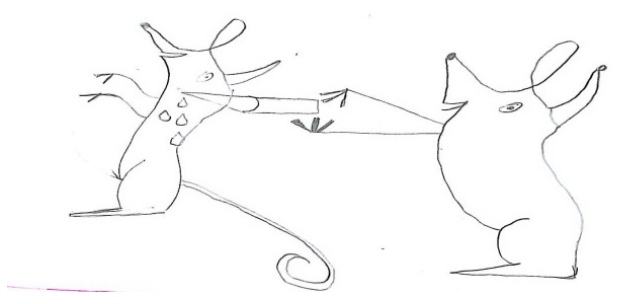

Figure 2. The argument of two mouse

A mouse did an ill turn to the other one and struggle with each other and this mouse stabs his dagger at the back of the other mouse. The mouse cries a lot and the other laughs and says that this is the respond of the evils you did to me in front of our house.

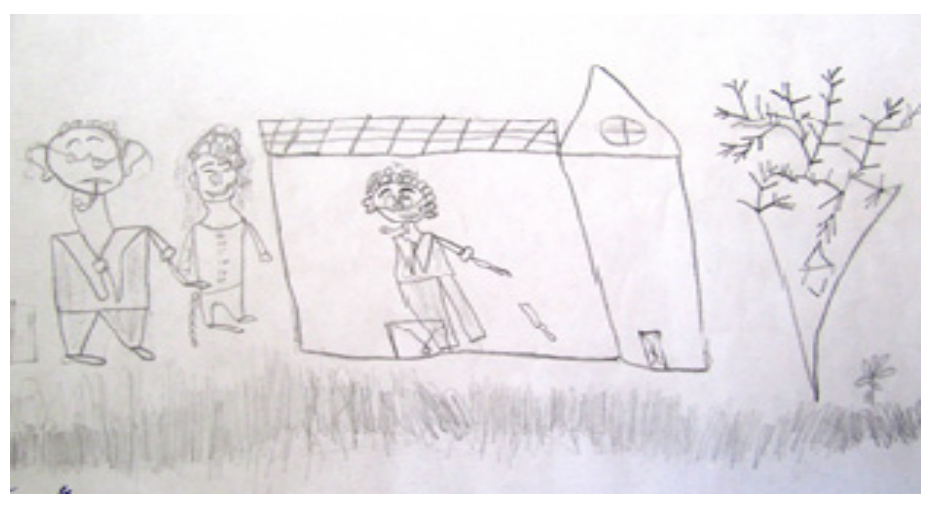

Figure 3. Not to forgive and killing the bride woman

Once upon a time, a woman and a piping man became familiar and married each other and after their marriage, they were searching a house. The houses were expensive. The man thought with himself that I buy a house from my father-in-law and then kill the bride. The groom hadn't money. The bride's father was forced to borrow two hundred million for him to buy a house. Then they got married. The groom said to the bride: come to the room I want to say a private thing to you. He took the bride into the room and killed her by a sharp knife and then he cried and said: I didn't want to do this. I was forced. The next day, he sold the house and escaped and went to the airport and he was arrested there.

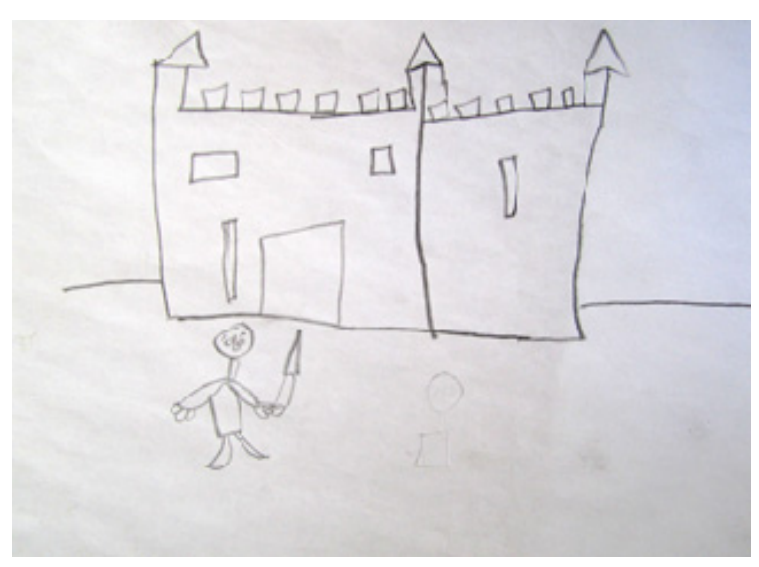

Figure 4 . The story of the soldier and the castle 
Once upon a time, there was a soldier who lived in a castle but he was the king before and one of his relatives has done something that he lost his kingdom. The soldier wanted to do something to take back the kingdom from the malicious man. At night he sent some unacquainted and he himself was with them. He killed all the soldiers guarding the castle and reached the control of the castle from them and the soldier became the king and helped people and the previous king was bad and didn't help people.

\subsubsection{Validity and Reliability of Research Tools}

In this research in order to evaluate the formal validity of the research, first we select 10 stories as the sample from the stories narrated by aggressive children based on the drawings based on DAS test and presented as analytic units to some educational sciences and psychology professors and educating exceptional children experts in the field of behavioral issues and asked them to suggest their view about each unit. The suggested ideas were investigated and compared with the researcher' view, so that the validity of the research was proved. In order to evaluate the reliability of the research method, first, a number of analytic units related to the children stories were selected and a form containing related categories (Appendix A) was prepared and given to the experts to recognize each analytic unit according to the triple aggressive components. After collecting the information, the solidarity coefficient between the selected categories by the experts and the categories by the researcher was analyzed. The results showed a range between $0 / 67$ and 1 for the aggressive components.

\section{Research Findings}

In order to evaluate the content of stories of aggressive children based on their drawings on DAS Test, the animated pictures, first, a graph was prepared for analyzing the stories and then according to the research questions, the findings were reported.

The extent that the stories content emphasized on the aggression components was the main issue of this study. And, this question is answered through content analysis of stories and analyzing the frequency of analytic units, including the aggressive components or not, and calculating the content engagement ratio of each story based on the appointed analytic units.

The findings which are mentioned in the Table 1 indicate the content analysis of the stories' texts told by aggressive children.

Table 1. Analyzing the stories' text narrated by aggressive children

\begin{tabular}{|c|c|c|c|c|c|c|c|c|c|c|c|c|c|c|c|c|c|c|c|}
\hline \multirow{3}{*}{ 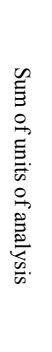 } & \multirow{3}{*}{ 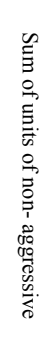 } & \multirow{3}{*}{ 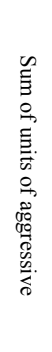 } & \multicolumn{16}{|c|}{ aggression components } & \multirow[b]{3}{*}{ 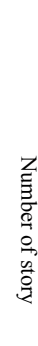 } \\
\hline & & & \multicolumn{6}{|c|}{ Reactive } & \multicolumn{6}{|c|}{ Proactive } & \multicolumn{4}{|c|}{ Physical } & \\
\hline & & & 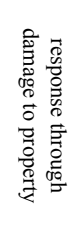 & 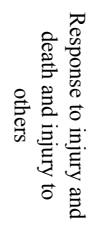 & 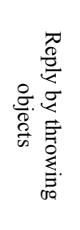 & 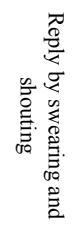 & 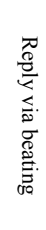 & 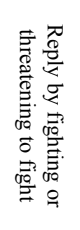 & 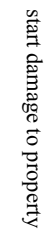 & 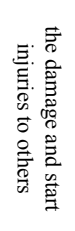 & 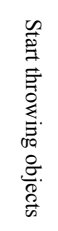 & 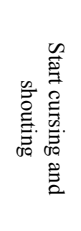 & 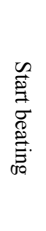 & 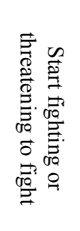 & 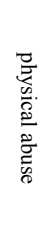 & 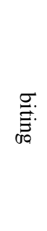 & 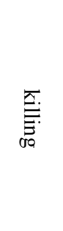 & 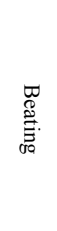 & \\
\hline 3 & 1 & 2 & - & - & - & - & - & - & - & 1 & - & - & - & - & - & - & 1 & & 1 \\
\hline 3 & 1 & 2 & - & 1 & - & - & - & - & - & - & - & - & - & - & 1 & - & - & - & 2 \\
\hline 3 & 2 & 1 & - & - & - & 1 & - & - & - & - & - & - & - & - & - & - & - & - & 3 \\
\hline 3 & 2 & 1 & - & - & - & - & - & - & - & 1 & - & - & - & - & - & - & - & - & 4 \\
\hline 3 & 1 & 2 & - & - & - & - & - & - & - & 1 & - & - & - & - & 1 & - & - & - & 5 \\
\hline 3 & 1 & 2 & - & - & - & - & - & - & - & 1 & - & - & - & - & - & - & 1 & - & 6 \\
\hline 3 & 0 & 0 & - & - & - & - & - & - & - & - & - & - & - & - & - & - & - & - & 7 \\
\hline 3 & 0 & 0 & - & - & - & - & - & - & - & - & - & - & - & - & - & - & - & - & 8 \\
\hline 3 & 0 & 0 & - & - & - & - & - & - & - & - & - & - & - & - & - & - & - & - & 9 \\
\hline 3 & 2 & 1 & - & - & - & - & - & - & - & - & - & - & - & - & 1 & - & - & - & 10 \\
\hline 3 & 1 & 2 & - & - & - & - & - & - & - & 1 & - & - & - & - & - & 1 & - & - & 11 \\
\hline 3 & 1 & 2 & - & - & - & - & - & - & - & 1 & - & - & - & - & 1 & - & - & - & 12 \\
\hline
\end{tabular}




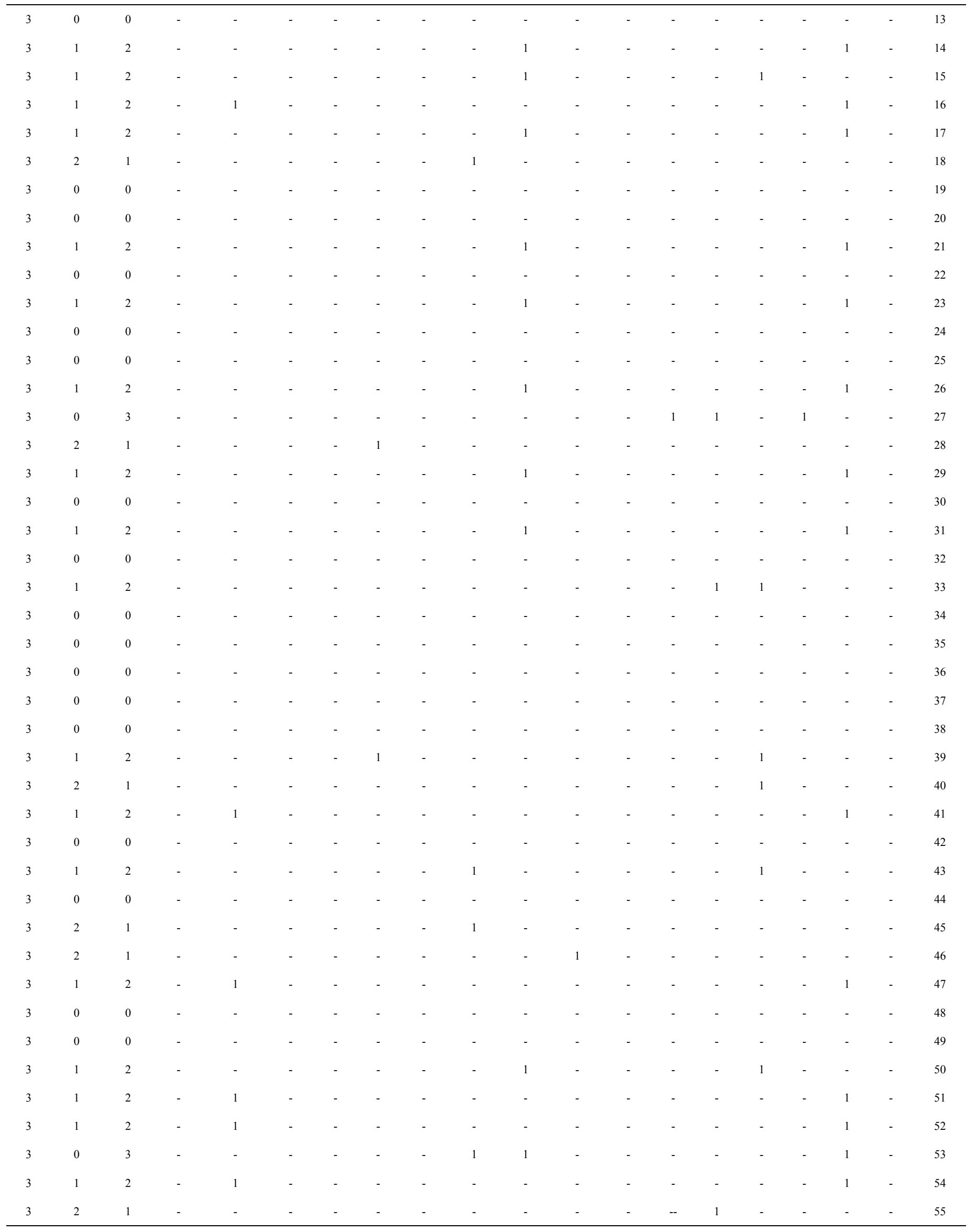




\begin{tabular}{|c|c|c|c|c|c|c|c|c|c|c|c|c|c|c|c|c|c|c|c|}
\hline 3 & 0 & 0 & - & - & - & - & - & - & - & - & - & - & - & - & - & - & - & - & 56 \\
\hline 3 & 1 & 2 & - & 1 & - & - & - & - & - & - & - & - & - & - & - & - & 1 & - & 57 \\
\hline 3 & 0 & 0 & - & - & - & - & - & - & - & - & - & - & - & - & - & - & - & - & 58 \\
\hline 3 & 0 & 0 & - & - & - & - & - & - & - & - & - & - & - & - & - & - & - & - & 59 \\
\hline 3 & 0 & 0 & - & - & - & - & - & - & - & - & - & - & - & - & - & - & - & - & 60 \\
\hline 3 & 0 & 3 & - & 1 & - & 1 & - & - & - & - & - & - & - & - & - & - & 1 & - & 61 \\
\hline 3 & 1 & 2 & - & 1 & - & - & - & - & - & - & - & - & - & - & 1 & - & - & - & 62 \\
\hline 3 & 1 & 2 & - & - & - & - & - & - & - & 1 & - & - & - & - & - & - & 1 & - & 63 \\
\hline 3 & 1 & 2 & - & - & - & - & - & - & - & 1 & - & - & - & - & - & - & 1 & - & 64 \\
\hline 3 & 0 & 3 & - & 1 & - & - & - & - & 1 & - & - & - & - & - & - & - & 1 & - & 65 \\
\hline 3 & 2 & 1 & - & - & - & - & - & - & - & - & - & - & - & - & 1 & - & - & - & 66 \\
\hline & & & 0 & 11 & 0 & 2 & 2 & 0 & 5 & 18 & 1 & 0 & 1 & 3 & 12 & 2 & 21 & 0 & \\
\hline$\stackrel{2}{\varrho}$ & $\stackrel{\infty}{+}$ & $\stackrel{\infty}{\sim}$ & & & & & & & & & & & & & & & & & $\stackrel{\Xi}{\Xi}$ \\
\hline
\end{tabular}

According to Table 1, the amount of disputing coefficient in the stories of the aggressive children with aggression components is $1 / 62$ indicating that more than $50 \%$ of them have aggression components. As we see, killing, injuring and murdering components have the most frequency and punishment, destruction, responding through throwing something, responding by argument and reviling have the least frequency in their imagination.

On the whole, by analyzing the amount of relationship between the stories' and aggressive component, coefficient, we can say that, aggressive children's stories, as far as acceptable, contain the aggressive components.

\section{Discussion and Conclusion}

Aggression is one of the external behavior problems which needs attention in its recognition treatment. This research aimed to study the content of children's stories according to the aggression components. The results showed that the amount of aggression components in the stories were acceptable. Content analysis of stories indicated that the most aggressive component is murdering and then hurting others. On the other hand, killing, murdering and hurting others in the imagination of aggressive children have the most abundance. Perhaps we can consider that such imaginations expressed in children's stories resulted from Medias such as television and computer or video games. Since, these days, such programs are so common among children. Researches show that six-year old children or older spend at least 2 hours of their time watching TV and playing computer games (Christakis, Ebel, Rivara, \& Zimmerman, 2004; said by Lan, Chang Abdullah, \& Roslan, 2010). Nowadays, the main components on TV children's programs are harshness and aggression (Violence, 1998; said by Lan \& colleagues, 2010). Harsh Media programs have short-time and long-time negative effects on the spectators specially children and teenagers (Coyne \& Archer, 2005; said by Lan \& colleagues, 2010).

The short time effects of TV relating to the increase of aggressive behavior with others are due to seeing harsh senses in them (Coyne \& Archer, 2005; said by Lan \& colleagues, 2010) and the longtime effects include the aggression of children to adults' crimes (Bushman \& Huesmann, 2006).

Before these researches, the studies of Bandura and Russ (1961) indicated that presenting harshness models and patterns increase the harsh treatment of the addressee as he/she shows himself/herself completely as the harsh character (Azari, 2008). Longitudinal and experimental studies on the effects of media harshness on children indicate that watching these programs causes aggression in the real life (Geen, 2001; said by Lan \& colleagues, 2010). Analyzing the role of Medias in creating the imagination and stories of children can be the topic of future researches.

The results of this research which is based on the high frequency of killing and injuring behaviors are the same as the results of Silver's studies (2005) which showed that physical and proactive aggression with attacking, injuring and killing people and animals are seen in their stories and drawings without any harsh motives. These people have high negative numbers in emotional content which means they have destructive, threatening or murdering relationships in describing a story. Such thoughts and imaginary during school years can be an alarm for the education experts to make influential interference on this topic. So, it is suggested that in order to decrease such problems we can try some methods like book therapy. In other words, some books for reducing aggression are 
suitable which can be considered as a tool for you to decrease the aggression in a delightful way (Parirokh \& Naseri, 2011). Obviously, the book cannot alone help the children to cope with problem. Discussing about the content of the stories and reminding them at necessary times help them to gain enough knowledge, correct their behavior and reach the equilibrium (Parirokh \& Naseri, 2011). Also by preparing instructing programs, by means of Medias like radio and television, and by holding instructing discussions at schools about accuracy in choosing computer games, parents and families will be informed about negative and bad influences of harsh and immoral plays on children and how to control the software and computer.

\section{Acknowledgements}

The researchers would like to thank all the students who participated in this study without which, this research could not have been.

\section{References}

Asadpour, K., \& H. Chary, M. (2010). Examination of the meaning of life from the perspective of Islam and religion in the lives of high school textbooks. Journal of Teaching and Learning, II(1), 1-32. [persian]

Azari, S. (2008). Play subsidy and violence. Research and Assessment, 15, 121-137. [persian]

Bushman, B. J., \& Huesmann, L. R. (2006). Short-term and long-term effects of violent media on aggression in children and adults. Journal of the American Academy of Pediatrics, 160(4), 348-352. https://doi.org/10.1001/archpedi.160.4.348

Card, N. A., \& Little, T. D. (2006). Proactive and reactive aggression in childhood and adolescence: A meta-analysis of differential relations with psychosocial adjustment. International Journal of Behavioral Development, 30, 466-480. https://doi.org/10.1177/0165025406071904

Chamandar, F., Shahim, S., Mazidi, M., \& Saif, D. (2013). Validity of the Draw a Story Test in Groups of Aggressive and Withdrawn Children. Journal of Cognitive and Behavioral Sciences, 2, 1-16. [persian]

Coie, J. D., \& Dodge, K. A. (1998). Aggression and antisocial behavior. In W. Damon (Series Ed.), \& N. Eisenberg (Vol. Ed.), Handbook of child psychology, Vol. 3: Social, Emotional, and Personality Development (5th ed., pp. 779-862). New York: Wiley.

Crick, N. R., \& Dodge, K. A. (1996). Social information-processing mechanism in reactive and proactive aggression. Child Development, 67, 993-1002. https://doi.org/10.2307/1131875

Crick, N. R., \& Grot peter, J. K. (1995). Relational aggression, gender, and social-psychological adjustment. Child Development, 66, 710-722. https://doi.org/10.2307/1131945

Crick, N. R., Casas, J. F., \& Mosher, M. (1997). Relational and overt aggression in preschool. Developmental Psychology, 33, 579-588. https://doi.org/10.1037/0012-1649.33.4.579

Dogde, K. A. (1993). Social-cognitive mechanisms in the development of conduct disorder and depression. Annual Review of Psychology, 44, 559-584. https://doi.org/10.1146/annurev.ps.44.020193.003015

Gentile, D. A., Mathieson, L. C., \& Crick, N. R. (2010). Media violence associations with the form and function of aggression among elementary school children. Social Development, 1-18.

Halporin, J. M., Mckay, K. E., \& Newcorn, J. H. (2003). Development, reliability and validity of the childrens aggression scale-parent version. Journal of American Academy of Child and Adolescent Psychiatry, 41, 245-253. https://doi.org/10.1097/00004583-200203000-00003

Hosseini Anjedani, M. (2008). The effect of watching violent cartoons on aggression. Research and Assessment, 15, 81-99. [persian]

Huesmann, L. R., Moisc-Titus, J., Podolski, C., \& Eron, L. D. (2003). Longitudinal relations between children's exposure to TV violence and their aggressive and violent behaviour in young adulthood: 1977-1992. Developmental Psychology, 39(2), 201-221. https://doi.org/10.1037/0012-1649.39.2.201

Ladd, G. W. (2006). Peer Rejection, Aggressive or Withdrawn Behavior, and Psychological Maladjustment from Ages 5 to 12: An Examination of Four Predictive Models. Child Development, 77, 822-846. https://doi.org/10.1111/j.1467-8624.2006.00905.x

Lan, K. L., Chang Abdullah, M., \& Roslan, S. (2010). Understanding Media Violence and the Development of Aggressive Behaviour of School Children. Procedia Social and Behavioral Sciences, 7, 522-527. https://doi.org/10.1016/j.sbspro.2010.10.070 
Marsee, M. A. (2003). Relational and Overt Aggression in Youth: Same Aggressive Tendency, Different Manifestations (Master of Dissertation). University of Alobama.

McEvoy, M. A., Estrem, T., Rodriguez, M. C., \& Olson, M. (2003). Assessing relational and physical aggression among preschool children: Intermethod agreement. Topics in Early Childhood Special Education, 23(2), 53-63. https://doi.org/10.1177/02711214030230020101

Parirokh, M., \& Nazareth, Z. (2011). Effect of treatment on aggression in children's programming-by-book. Academic Journal of Children's Literature at Shiraz University, Year II(1), 33-59. [persian]

Poulin, F., \& Boivin, M. (2000). Reactive and instrumental aggression: Evidence of a two-factor model. Psychological Assessment, 12, 115-122. https://doi.org/10.1037/1040-3590.12.2.115

Raine, A., Dodge, K., Loeber, R., Gatzke-Kopp, L., Lynam, D., \& Reynolds, C. (2006). The reactive-proactive questionnaire: Differential correlates of reactive and proactive aggression in adolescent boys. Aggressive Behavior, 32, 159-171. https://doi.org/10.1002/ab.20115

Schwartz, D., Dodge, K. A., Coie, J. D., Hubbard, J. A., Cillessen, A. H., Lemerise, E. A., \& Bateman, H. (1998). Social cognitive and behavioral correlates of aggression and victimization in boys' play groups. Journal of Abnormal Child Psychology, 26, 431-440. https://doi.org/10.1023/A:1022695601088

Shahim, S., \& Razmjoee, M. (2009). Self image and emotional content in aggressive and non-aggressive children. Presented at the Congress of art therapy, Tehran. [persian]

Silver, R. (1989). Developing Cognitive and Creative Skills Through Art. New York: Albin Press.

Silver, R. (2005). Aggression and Depression Assessed through Art. Using Draw-a-Story to Identify Children and Adolescents at Risk. NewYork: Brunner Routledge.

Susan, A. (1995). The Stories Children Tell. Making Sense of the Narratives of Childhood. United States of America: W. H. Freeman and Company.

Walker, H. M., Colvin, G., \& Ramsey, E. (1995). Antisocial behavior in schools: Strategies and best practices. Pacific Grove, CA: Brooks/Cole.

Werner, R. S., Cassidy, K. W., \& Juliano, M. (2006). The role of social-cognitive abilities in preschoolers' aggressive behavior. British Journal of Developmental Psychology, 24, 775-799. https://doi.org/10.1348/026151005X78799

Woodworth, M., \& Porter, S. (2002). In cold blood: Characteristics of criminal homicides as a function of psychopathy. Journal of Abnormal Psychology, 111, 436-445. https://doi.org/10.1037/0021-843X.111.3.436

Xie, H., Farmer, T. W., \& Cairns, D. C. (2003). Different forms of aggression among inner-city African-American children: Gender, configuration. And school social networks. Journal of School Psychology, 41, 355-375. https://doi.org/10.1016/S0022-4405(03)00086-4

Yarly, J. (2005). Content analyzed of Junior high school civics textbooks to develop the skills to communicate with others education of the Esfahan province: Expert of research. [persian]

\section{Copyrights}

Copyright for this article is retained by the author(s), with first publication rights granted to the journal.

This is an open-access article distributed under the terms and conditions of the Creative Commons Attribution license (http://creativecommons.org/licenses/by/4.0/). 